Acta Orientalia Academiae Scientiarum Hung. Volume 54 (4), $485-496$ (2001)

\title{
TWO FIRMANS OF MUSTAFĀ II ON THE REORGANISATION OF THE OTTOMAN COURIER SYSTEM (1108/1696)
}

\author{
(DOCUMENTS FROM THE THESSALONIKI CADI SICILLS)
}

\author{
COLIN HEYWOOD* \\ (Wendover)
}

\begin{abstract}
The present article publishes text and translation of two firmans of Mustafā II, dated 1108 (1696), taken from copies in the cadi registers (sicill) of Thessaloniki, regulating the reform of the Ottoman state courier and post-station (ulak/menzilhāne) network with regard to the Rumelian sol kol (Via Egnatia). The firman texts are designed to be studied in conjunction with the commentary in the author's study of the Rumelian sol kol in E. Zachariadou, The Via Egnatia under Ottoman Rule (1380-1699) (Rethymnon 1996), pp. 129-144.
\end{abstract}

Key words: Ottoman Empire, economic and social history, 1453-1699; Rumeli, history and historical geography; the Ottoman ulak.(courier) system, history; Via Egnatia, history (1380-1699); Ottoman paleography and diplomatics.

In 1977, when I was engaged in collecting material preserved in the Turkish state archives for a study of the rise and development of the Ottoman ulak.or state courier and post-station network, it soon became evident that the plethora of archival material on the subject for the eighteenth century, when compared to its scarcity for earlier periods, was due to no random process of fortuitous survival or archival accessibility. In two preliminary contributions to the subject, both of which were written in Istanbul when my research was in its early stages, I was able to establish that this proliferation of the records of the ulak.system reflected a thoroughgoing reorganisation of the administrative and financial bases of the system, at both central and provincial levels, which had been undertaken by the Ottoman authorities during the first decade of the twelfth/last decade of the seventeenth century, particularly in the years A.H. 1103 (September 1691-1692) and 1108 (July 1696-1697). It became clear also that this reorganisation had transformed the state courier system in a way which would determine its characteristics as an operating system throughout the twelfth and early to mid-thirteenth/eighteenth and early nineteenth centuries, down to the intro-

${ }^{*}$ Colin Heywood, Department of History, School of Oriental \& African Studies, University of London, Thornhaugh Street, Russell Sq., London WC1H 0XG, United Kingdom, e-mail: dragomanate@aol.com 
duction of a reformed postal courier system by Mustafā Reshīd Pasha in 1255/1839 as part of the ongoing reforms of the Tanzimat period. ${ }^{1}$

In this preliminary research I was also able to establish the date - Rūz-1 Hizır 1108, i.e., Hidrelles (< Hızır İlyās) or St. George's Day, 23 April 1697 Julian / Old Style $^{2}-$ on which the second (and final) principal reorganisation of the system was due to take effect, and also to point out its chief characteristics. ${ }^{3}$ In the time - unfortunately curtailed through illness - which remained to me in the Turkish archives, the texts of the one or more firmans which must have been issued to give instructions to the relevant provincial authorities regarding the reorganisation of the system managed to elude me, although their 'ghosts' were evident through fragmentary references in entries in a number of other defters relating to the ulak.system. ${ }^{4}$

By a happy chance, and through the kindness of my old friend Professor Vassilis Demetriades, I was enabled subsequently (in 1978) to obtain copies of the texts of the two 'reorganisation firmans' in question, and to confirm that my suppositions regarding their existence had been correct. The texts of the firmans were located, not in the Turkish central archives, but in the surviving sicills or Sharī'a court records of the cadis of Thessaloniki, the lengthy series of which, stretching from the late seventeenth century to the early twentieth, are now preserved in the Provincial Archives of Macedonia at Thessaloniki. The two firmans in question were issued, in the name of the Ottoman sultan Mustafă II (1106/1695-1115/1703), at Edirne on 10 and 15 Rebī' II, 1108 (27 October [Old Style, = 6 November, New Style] and 1 [Old Style, $=11$, New Style] November 1696). The sicill volume in which their arrival was recorded (on 27 Cumā $7 \bar{a}$ II 1108 (12/22 January 1697) by the cadi of Thessaloniki - the documents having presumably arrived together by the same courier - and in which their texts were entered (on pp. 186-188), forms vol. 2 of the present series of Thessaloniki cadi court records. ${ }^{5}$

In a later contribution on the Ottoman 'Route of the Left Hand' in Rumeli, which was written for Professor Elizabeth Zachariadou's second 'Halcyon Days in

\footnotetext{
${ }^{1}$ Heywood (1976-1977, and 1980).

2 The fiscal administration of the Ottoman ulak.system, as of much else, was based on a solar year calendar beginning on Rūz-i Hiżır and divided into two roughly equal (resp. summer and winter) halves by Rūz-i Kāsım (Kasım günü; St. Demetrius' Day), 26 Oct. O.S. (Cf. Fekete 1955, pp. I, 72). Rūz-i Hıżır fell twelve days after Nevrūz, the Persian New Year (1 Farvardīn), which fell on 11 March Old Style, and which - as the maliyye year - was used, at least in the sixteenth century, for budgetary purposes (cf. Sahillioğlu 1970, p. 233). For the seventeenth century, however, according to Professor Sahillioğlu, the indications as to whether the hicrī or the mäliyye year was employed are unclear. In relation to the hicri calendar, in A.H. 1108 (31.7.1696-19.7.1697), for example, Rūz-i Kāsım (26 Oct. 1696) must have preceded Rūz-i Hıżır (23 April 1697). Inferences regarding the references to the two days in the present documents would appear to indicate that the hicri year was intended.

${ }^{3}$ Heywood (1980, pp. 182, ff.).

${ }^{4}$ E.g. in various annotations der kenār in BA KPT 2742, Defter-i menāzil-i Rūm İli ... der sene 1104 (1692-1693) ilā sene 1105 (1693-1694) and KPT 3006, Defter-i menāzil-i bārgīrān-i ulak.der vilāyet-i Rūm İli (dated 1124-1125/1712-1713); cf. Heywood (1980, pp. 180, 185, note 8).

${ }^{5}$ Information received from Professor (then Dr) Vassilis Demetriades, at the time Director of the Provincial Archives of Macedonia, in June 1978.
} 
Crete' Symposium, held at Rethymnon in 1994 on the subject of the Via Egnatia under Ottoman rule, I was able to quote extensively from the two reform firmans of $1108 / 1696$ and comment further on them; space was lacking, however, to publish the texts (and translations) in their entirety. ${ }^{6}$ Although their significance cannot be fully appreciated without further investigation of the ulak.system as it existed both before and after the event, the publication of the post-reform nizām-nāmes for the Rumelian kollar, on which I have been long (if intermittently) engaged, has proved to be a somewhat protracted task. ${ }^{7}$ It would seem worthwhile, therefore, to publish in the interim the Reorganisation Firmans of Mustafā II, independently of the nizām-nāmes which derive from them. It is a pleasure and a duty to honour on the present occasion the evergreen memory of Lajos Fekete, whose pioneering work in Ottoman paleography and diplomacy continues to provide both a model and a standard for workers in the field.

The texts and translations of the two firmans are given below. ${ }^{8}$

\section{The documents}

I.

Firman [of Mustafā II], addressed to the cadis stationed on the road from Edirne to İstife (Thebes); i.e., on the Rumelian Sol kol, or Route of the Right [Hand]), reforming the operation of the state courier (ulak) and relay-station (menzilhāne) system. Cadi's copy. Issued at Edirne, $10 \mathrm{Reb}^{\top}{ }^{`} \mathrm{II}, 1108$ (27 October [O.S. $=6$ November, N.S.] 1696); received at Thessaloniki, 27 Cum. II, 1108 (= 11/21 January 1697).

Thessaloniki, Provincial Archives of Macedonia, Cadi of Thessaloniki, court entrybooks, 'I 2 . 2, pp. 186-188; 53 lines (pp. 186, 11. 17-31; 187 (35 lines), and 188, 11. 1-3).

186 17 Mefāhirü'l-kużāt ve'l-hükkām / ma'denü'l-fażl ve'l-kelām / Edrene'den İstifeye varınca yol üzerinde vākı' olan kāżīlar - zide fażluhum - /

ve mafharu'l-emāșil ve'l-akrān kethüdā yerleri ve yeñiçeri serdārları ve a'yāni vilāyetiñ iş erleri ve menzilciler - zide kadruhum - / tevkí'-i

refí‘-i hümāyūn vāsıl olıcak.ma'lūm ola ki / hālā Rūm İli ve Anatolı cāniblerinde vākı' menāzil kadīmden ancak.umūr-i mühimme-i

20 dīn-ü-devlet içün vaż‘ olunub / ulu yol üzerinde olan każālarda vākı' her menziliñ masārifiçün ekșeriniñ

taraf-i Mīrīden mu'ayyen köyleri <olub> ve ba'żısınıñ hazīne<-i> 'āmireden ve ba‘żı emvālden havāleleri ve każālardan imdādiyesi

\footnotetext{
${ }^{6}$ Heywood (1996).

${ }^{7}$ BA KPT 2742 and 3006 (see above, note 4).

${ }^{8}$ For technical reasons the texts are provided in transcription.
} 
olub / ve ulu yolda olmayan każālarda dahi ulak.mütemādī olmag̉la mu'ayyen menzil olmayub ancak.

iktiżā eyledikde ahāli-i każā kendü beynlerinde göregelmelerile ol-ma'kūleleriñ hazine defterlerinde kaydı olmayub

ve senede ne-mikdār menzil maSrafları olduğı ma'lūm degildir / hālā Devlet-i 'Aliye tarafından hükm-i hümāyūn ile umūr-i mühimme ile

25 murūr ve 'ubūr eden ulaklardan mā'adā etrafda olan ser-'askerler ve serhadd-i mansūreler muhāfazasında ve taşra

mansıblarında olan vüzerā-yi 'izām ve sāir mīrmīrān ve mīr-livā ve mütesellimleri umūr-i mühimmeden-gayri cüzvī

ve kendi maslahatlarıçün dahi menzil bārgīrlerine buyuruldı vermelerile bu tarīk.ile kesret-i menāzil

vāk1' olmag̀la 'an asl umūr-i mühimme içün mevcūd olan menzil bārgīrleri bir vechle tākat getürmeyüb bārgīrleri

telef ve menzil kurāsınıñ re'āyāsı dahi perākende olmalarıle umūr-i mühimme ile giden ulakları̃̃ ta'tīline bā'is

30 olduklarında yine taraf-i Mīrī’ den ve civārında vākı‘ olan każālardan başka imdād verildüginden gayri niçesin

dahi re‘āyā fukarāsı kendü beynlerinde çeküb bu kesret-i menāzil sebebile cānib-i Mīrī’ye żarar ve re‘āyā fukarāsına

1871 küllī Zulm ve ta'addī olundug̣̀ tevātür ile nümāyān olmag̉la bi’l-cümle menāzil ref' ve bundan böyle menzilciler kendüleri

bārgīr besleyüb ve her bir menzile ücret takdīr ve murūr ve 'ubūr eden ulaklara ücret ile bārgīr verilüb mukāta'a olmak.

şartıle vilāyet-i Rūm İli ve Anatolı'da vākı' menziller müceddeden tertīb ve bir Sūrete ifrāg olunmak.üzere fermānım

olub gene kadīmī menzil tertībi şimdiden ref olunduğı hālde sūret-i ahar tertībine menzilcileriñ vüs'at

5 ve iktidārları olmayub / tertīb-i cedīd nizāmıñ bulmak. içün hālā menzillerde mevcūd olan menzil bārgīrleri

ve masārifiçün mu'ayyen olan akçeleri altı aya degin sermāye olmak.üzere inşā'llāhu ta‘ālā biñ yüz sekiz

senesi Rūz-1 Hıżırına varınca yerlerinde ibkā ve işbu biñ yüz sekiz senesi Rūz-

i Kāsım'ında bi'l-cümle Rūm İli ve Anatolı

cāniblerinde vākı' < gerek> mu'ayyen ve gerek gayrī-mu'ayyen menāzilden murūr ve 'ubūr eden ulaklara fīmāba'd ücret ile bārgīr verilüb

ancak. bu menzilleriñ birbirinden tefāvüti olub ba'ż1sı karīb ve ba'żısı dahi ba'īd olub müsāvī olmamag̉la

10 her menziliñ bārgīr ücretleri sā'at hesābınca ta'yīn ve takdīr olunmak.iktizā etmegin bir bārgīre her bir sā'at

yol içün onar Sag̉ akçe ücret takdīr olunub bundan böyle Devlet-i 'Āliyem ve gerek Kırım Hānı ve etrāflarda olan

ser-'askerler ve serhadd-i mansūreler muhāfazasında olan ve taşra mansıblarda teftīşle olan vüzerā-yi izām ve sāyir 
mīrmīrān ve mīr-livā $<$ ve $>$ mütesellimleri taraflarından gerek mu'ayyen ve $<$ gerek $>$ gayrī-mu'ayyen olan menzillerde murūr ve 'ubūr eden ulaklara takdīr olan ücretile bārgīr verilüb / eger sürici ve kulag̉uz taleb eder olur ise $<$ gerek $>$ a'lā ve gerek

15 ednā kendi bineklerinden-gaayrī sürici ve kulag̉uz ve gerek eşyāları tahmīl içün kaç bārgīr alurlar ise ke-zalik yine

ta'yīn olunan ücretile verilüb / ve ulaklar menzilcilerden müft ve meccanen yemek yemeyüb ta'āma göre

rızāsı ve bahāsı ile alub / bundan soñra gerek hükm-i hümāyūn ve gerek buyuruldı ile murūr ve 'ubūr eden ulaklara $<$ gerek $>$

mu'ayyen ve gerek ġayrī-mu'ayyen olan menāzilde ve gerek kaSabāt $<$ ve $>$ kurāda bilā-ücret bārgīr ve müft<-ü->meccānen yemek verilmeyüb

eger hilāf-i şer'-i şerīf ve mugàāyir-i emr-i hümāyūn cebren bilā-ücret bārgīr ve müft $<$-ü $>$ meccānen yemek talebile ta'addī ve tecāvüz

20 eder olur ise ol ma 'kuleleri hākim-i vilāyet olanlar men' ve def" eyleyüb mem$n \bar{u}$ ' olmayanları ism ve resmlerile

ve şöhretlerile Dīvān-i Hümāyūnuma 'arz-ü-i'lām eyleyeler / el-hāsıll bundan böyle cümle menzil bārgīrleri mekkārī misilli

olub ahir kimesneler dahi bir mahallden bir mahalle kendi umūrlarıçün menzil ile gitmek tālib olanlara ižn-i 'āmdır /

fermān taleb olunmayub ta' yīn olunan ücret ile menzil bārgīi verilüb

ve menzilciler dahi iktizā eyledügi mikdārı bārgīr besleyeler / ve biñ yüz sekiz senesi Rūz-1 Kāsım'ından sene-i mezbūre

${ }_{25}$ RūZ-1 Hıżır'ına varınca yevmiye vākı' olan ulaklara verilen menzil bārgīrleri taraf-i şer'den żabt ve defter olunub

ve ücretden hāsıl olan akçeyi menzilci olanlar taraf-i Mīrī'den emānete żabt ve a'yān-i vilāyet ma'rifetleri ile

hıfZ olunub / Rūz-1 Hıżır duhūlinde her menzilciniñ hesābı görülüb ve müctemi`olan ücret akçesin

Der-i-Sa'ādetime irsāl ve teslīm-i Hazīne-i 'Āmire etdirile ve İnşā’llāhu ta‘ālā Rūz-i Hıżı'’a degin bu vech üzere

her menzil nizāmın buldukda 'atîk. menzil tertībi ref' olunub ve andan soñra her menzilden

${ }_{30}$ hāsıl olan ücret akçesile menzil maSārifi görülüb / maSrafdan ziyādesi teslīm-i Hazīne'ye

eylemeleri üzere mukāta'a olub / a'yān-i vilāyet ma'rifetile iltizāmile menzilcilere der-'uhde olunmak.üzere

emr-i şerīfim tahrīr olunmak.bābında 'arz-ü-telhīs olundukda / imdi telhīs mucibince mahalline kayd ve fïmāba'd

destūrü'l-'amel olunmak. bābında fermān-i 'ālisşānım sādır olunmuşdur / buyurdumki

hükm-i şerīfimle

$<$

fermān-i celīlü'l-kadrım mucibince

> vardıkda bu bābda Sādır olan 
35 'amel edüb dahi vech-i meşrūh üzere irsāl olunan sūret-i defterde mukayyed olan her menzil każālarında

188 1 sicillde kayd ve sūretleri imżālanub / menzilcileriñ yedlerine verilüb / işbu emr-i şerīfimiñ hilāfına

bir ferde vaż' ve hareket etdirmeyesin / şöyle bilesin / 'alāmet-i şerīfe i'timād k1lasin /

tahrīren fî'l-yevmi’l-‘āşır < min> şehr-i Rebī'ül-ahir li-sene șemān ve mi’e ve elf.

$$
\begin{gathered}
\text { Bi-makāmi } \\
\text { Edrene } \\
\text { el-mahrūsa }
\end{gathered}
$$

\section{[Annotated:]}

Vusila fì 27 min Cumā7ā’l-evvel sene 1108

\section{Translation}

Ornaments of the cadis and judges; mines of virtue and eloquence: the cadis [of places lying] along the road from Edirne to İstife - may their virtues be increased! and ornaments of the most eminent and [their] peers, commandants of the provincial cavalry (kethüdā yerleri) and Janissary commanders (yeñiçeri serdārları) and agents (iş erleri) of the provincial notables ( $a^{\prime} y \bar{a} n-i$ vilāyet) and post-station keepers (menzilciler) - may their power be increased!

When the Noble Imperial Sign shall arrive, let it be known that the post-station[s] (menzil) existing at present in Rumeli and Anatolia, were established in the past solely for use in connection with important affairs of state (umūr-i mühimme-i dīn-ü-devlet). For the [operating] expenses (masārifiçün) of each post-station in ka$\dot{z} \bar{a}$ s [which lie] on main routes (ulu yollar), the greater part is [provided by the inhabitants of] villages designated [for the purpose] (mu'ayyen) on the part of the State Treasury (Māliye tarafindan); some from the Imperial treasury (Hazine-i 'Ámire), and some from transfers of funds (emvālden havāleleri) and grants-in-aid (imdādiyye) from [the revenues of neighbouring] każass. Furthermore, in każas which are not on the main route, and where there is no designated post-station, yet when need arises because couriers are continually [passing through], the people of the każa meet [the expenses] among themselves. Hence there is no entry for [post-stations of] this type (makūle) in the Treasury Registers (Hazine Defterleri), and [as a consequence] the [total] annual cost of the post-station [network] is not known.

At present, apart from couriers going to and fro on important matters [on journeys sanctioned] by Imperial [courier-]orders ([ulak] hükmi) issued by the Porte, military commanders in the various sectors, viziers charged with the defence of the frontiers or holding provincial appointments, and other beylerbeys and sancak-bey[s] 
$(m \bar{r} r-l i v \bar{a})$ and their deputies issue orders (buyuruldl) for post-horses (menzil bārgìrleri) for [use in] unimportant and trifling matters and even for their own affairs.

As a result, numerous post-stations have been set up, and the post-horses, which exist basically ('an $a s l$ ) for [use on] important matters, being quite unable to cope with the work, the horses are [worked to] death, and the people of the villages [allocated to servicing] the post-station[s] are ruined. Because [these circumstances] caused interruptions to couriers engaged on important matters, not only was further [financial] assistance given from the State Treasury and from the neighbouring każās, but many [expenses] too were borne by the people collectively, so that it is incontestably clear that through this excessive number of post-stations there occurs loss to the treasury and all [kinds of] tyranny and oppression to the people.

Therefore My firman is that all the post-stations are to be abolished, and that henceforth the post-station keepers shall maintain the horses themselves. A fee (ücret) is to be established for each stage; and horses are to be issued to couriers on a journey against the [payment of the stipulated] fee. The post-stations in Rumelia and Anatolia are to be organised anew and shaped into a [new] form with the stipulation that each [station] be [constituted] a [separate] tax-farm (mukāta 'a olmak.şartıle).

Nevertheless, if the old post-station organisation is abolished straight away, the post-station keepers lack the means and the power to organise another system. So, in order that the new organisation may be regularised (tertīb-i cedīd nizämin bulmak içün), the post-horses at present at the post-stations and the moneys allocated for their expenses are to be retained where they are for six months, if God - He is exalted! - wills, until Rūz-i Hıżır of 1108 [= 23 April 1697]. On Rūz-i Kāsım of this year 1108 [= 26 October 1696], at every post-station in Rumelia and Anatolia, both designated (mu'ayyen) and undesignated ('gayri-mu'ayyen), post-horses are to be issued to couriers en route against a fee. However, [since] there is disparity [in the distance] between one and another (birbirinden tefāvüti) of these post-stations, some being near and some in fact far [from one another] and not [therefore] equi[distant], it is needful to institute and lay down post-horse fees for each post-station on a calculation by time. The fee is established at ten sound akçes for each horse for each hour's travel (bir sā'at yol içün). From then on horses are to be issued at the established fee to couriers en route, at both designated and undesignated post-stations, when travelling on behalf of My Porte, the Hān of the Crimea, military commanders in the various sectors, viziers charged with the defence of the frontiers or holding provincial appointments as inspectors, and other beylerbeys, sancak-beys and their deputies. If [an official], whether he be of high or of low rank, requests a postboy (sürici) or a guide (kulagiuz), however many horses he may take besides his own saddle-horses for the postboy or the guide or to transport his luggage, they are to be issued in the same way $(k e-\underline{z} a l i k)$ at the prescribed fee.

Couriers in future shall not eat free or subsidised meals (müft ve meccānen yemek yemeyüb) [at the expense of] the post-station keepers; henceforth they shall take [them] by agreement and at a price [corresponding to the cost of] the food [consumed]. Henceforth [the post-station keepers], either at designated or at undesignated post-stations, or [other officials] in townships and villages [on the road] shall not fur- 
nish [post-] horses without a fee, or free or subsidised meals, to couriers coming and going either [on the basis of] Imperial orders or ministerial commands (buyuruld $\iota$ ). Should [the couriers] commit extortion and excess through seeking free or subsidised food, or by forcibly [taking post-]horses without [paying] the [stipulated] fee, in contravention of the Noble Shar' ${ }^{-}$a and in violation of [My] Imperial Command, let those who possess authority in the province prevent and restrain such people and let them bring to the notice of My Imperial Council (Dīvān-i Hümāyūnum) the names and descriptions and characters (ism ve resm ve şöhret) [of the offenders].

In brief, henceforth all post-horses are to be treated like pack-horses (mekkāri misillü). And there is a general permission to other persons too, who wish to make use of the post[-station] network (menzil ile) in travelling on private business from one place to another. No firman need be requested, but horses are to be issued against [payment of] the prescribed fee. Post-station keepers for their part (dahi) must maintain the necessary number of horses [for such private users].

The post-horses issued to couriers who present themselves day by day from Rūz-i Kāsım of the year 1108 to Rūz-i Hiżır of the same year are to be recorded and listed (zabt ve defter olunub) by the [local cadi's] court authorities. The [present] poststation keepers shall exercise trusteeship on behalf of the Treasury, and with the cognizance of the notables of the province the money which accrues from the [hiring-] fees shall be retained, and the accounts of each post-station shall be made up (hesā $b$ r görülüb) at the beginning of [each] Rūz-i Hiżır, and the [hiring-]fee moneys which have been collected together shall be sent and delivered to the Imperial Treasury.

My Firman has been issued to the effect that: when by Rūz-i Hiżır 1108 [= 23 April 1697], if God - He is exalted! - wills, each post-station is to be organised in this way, the old post-station system is to be abolished, and thenceforth the post-station expenses shall be met from the hiring-fees which accrue. The surplus after payment of expenses is to form [the profit margin of?] a tax-farm (mukāta 'a). When an official notification ( $i$ 'lam $)$ is submitted with the cognizance of the notables [of a province] for the writing of My command that [a particular post-station] be entrusted to the post-station keepers in the form of a [tax-]farm, it [= My Command?] is to be noted in the appropriate place on it, in accordance with the draft submission (telhīs), and to be put into effect.

I command that on the arrival < of N. N.> with My Noble Order, you are to act in conformity with My command replete with authority; furthermore, on the basis of the foregoing, you are to enter [the text of the firman] into the [cadi's] Register (sicill) in each każā in which a post-station is situated, and to cause copies which you are to authenticate to be put into the hands of the post-station keepers. And you are to prevent and restrain anyone from transgression of this My Noble Command.

Thus you are to know; you are to place reliance on the Noble Sign.

Written on the tenth day of the month of Rebi' $\ddot{u} l-A$ hir in the year one thousand, one hundred and eight.

\author{
In the Residence of \\ Edirne \\ the Well-Guarded
}




\section{[Annotated:]}

'It was received on 27 Cumā $7 \bar{a} ' l-E v v e l$ of the year 1108.'

\section{II.}

Firmān [of Mustafā II], addressed to the cadis stationed on the [Rumelian] sol kol ('[Route of the] Right [Hand]'), issuing further instructions concerning the reform of the operation of the state courier (ulak) and relay-station (menzil) system. Cadi's

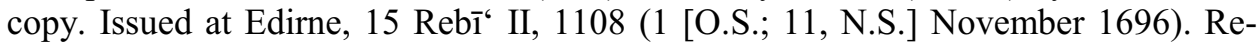
ceived at Thessaloniki as in Document I.

Thessaloniki, Provincial Archives of Macedonia, Cadi's court entry-books (sicillät), 'IEp. 2, p. 188, 24 lines (11. 4-27).

1884 Mefāhirü'l-kużāt ve'l-hükkām / ma‘denü'l-fażl ve'l-kelām / vilāyet-i Rūm İli'nde sol kolda vākı' mu'ayyen menzil olan menzilleriñ kāżìları zīde fażluhum / ve mefāhirü'l-emāsil ve'l-akrān / kethüdā yerleri ve yeñiçeri serdārları ve a'yān-i vilāyetiñ iş erleri zīde kadruhum / tevkī'-i refî'-i hümāyūn vāsil olıcak.ma'lūm ola ki / vilāyet-i Rūm İli ve Anatolı cāniblerinde ulu yollarda

vākı' menzil defterinde mukayyed menāzile kadīmde $<\mathrm{n}>$ maktū' olan menzil bārgīrleri içün ekșeriniñ 'avārıż ve nüzūlları mukābelesinde mu'ayyen menzile bağlu köyleri olub / lakin seferler mümtedī olmak. hasebile keśret-i menāzilde kadīmī bārgīrleri kifāyet eylemedikçe ba 'żısına Hazīne’den ve ba ‘żı emvālden havāle ve civārında olan każālardan imdād verildükde

10 yine ziyāde masārif içün her menziliñ każā ahālisi < ...?> beynlerinde akçe sālyāne olunub ve bunlardan-ġayrī

menzil defterlerinde kaydları olmayub ulu yollarda olmayan ba'żı każālara dahi iktiżā hasebile ulak. ug̉ramag̉la kazā ahālisi beynlerinde menzil içün bārgīr besleyüb / lāzim gelen menzili masārifde każā ahālisi

kendüleri çeküb / bu vechle menāzil husūsında cānib- Mīrīye zarar olunduguundan ġayrī re'āyā fukarāsına

dahi küllī Zulm ve ta'addī olmağla bi'l-cümle Rūm İli ve Anatolı'da olan menziller yüz sekiz Rūz-1 Hıżır'ında

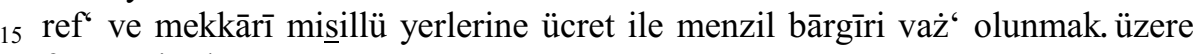
fermān-i 'ālīşānım

Sādır olub / defterde ismi olub mu'ayyen olan menzillerde ve gerek defterde ismi olmayub mu'ayyen olmayan

każālarda hāliyā kaçar menzil bārgīri beslenür senede ne-mikdār akçe maSrafları olur ve menzil kurāsı ne-mikdār

akçesin verir ve ne-mukābelede verirler ve cānib-i Mīrī'den Hazīne'de $<\mathrm{n}>$ ve ba'żı emvālde $<n>$ havāle ile verilen 
ve $<\ldots$ ? > kazālarda $<$ n? $>$ imdādı fermān olunandan $<$ ? > mā'adā Mīrī olan menzillerde $<$ n $>$ ziyāde maSraf iktizāsıle

20 verdikleri akçe ve mu'ayyen menzili olmayan każālarda besledikleri menzil bārgīrleri içün < ancak!> każā

ahālisi senede verdikleri ne-mikdār akçedir / ve bir menzilden bir menzile varınca beynlerinde kaçar sā'atdir / sıhhati ve hakīkatı üzere menzilleriñ ma'rifet-i şer'le sā'atlerin dahi tefahhus ve ma'lūm-i hümāyūnum olmak.

içün rikāb-i hümāyūnuma 'arz<-ü->i'lām eyleyesiz deyü fermānım olmuşdur / buyurdumki hükm-i şerīfimle

$<\quad>$ vardıkda bu bābda Sādır olan

emrim üzere 'amel edüb dahi husūs-i mezbūrı

25 minvāl-i meşrūh üzere sıhhatin ve hakīkatın ma'rifet-i şer'le tefahhus ve ma'lūm-i hümāyūnum olmak.içün

rikāb-i hümāyūnuma 'arz<-ü->i'lām eyleyesiz / şöyle bilesiz / 'alāmet-i şerīfe i'timād kılasız / tahrīren fî̀l-yevmi’l-hāmis-'aşır <min > şehr Rebī'ül-ahir sene semān ve mī’e ve elf

$$
\text { bi-makāmi }
$$

Edrene el-mahrūsa

\section{[Annotated:]}

vusila $\mathrm{f}$ $\overline{1}$

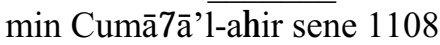

\section{Translation}

1 Ornaments of the cadis and judges; mines of virtue and eloquence, the cadis of [places possessing] designated post-stations on the Route of the Left [Hand] in the vilayet of Rumeli - may their virtues be increased! - and ornaments of the most eminent and [their] peers, commandants of the provincial cavalry and Janissary commanders and agents of the provincial notables - may their power be increased!

3 For [the expenses of] the post-horses assigned (makt $\bar{u}$ ) of old to the poststations enregistered in the register of post-stations situated on the main routes in the vilāyets of Rumeli and Anatolia, the greater part was [supplied by] villages attached to the designated post-station in return for [exemption from] 'avāriz and nüz $\bar{u} l$ [taxes]. However, as the post-horses [allocated] of old ceased to be sufficient with the increase in [the use of] post-stations as a result of the prolongation of the war, some [of the expenses] were provided for from the Treasury, and some by transfer of [local] revenues and by grants-in-aid from $k a z \bar{a}$ s in the vicinity. All the same, to meet the [excess of expenditure], money was levied annually among the local people of the population of the każa in which each post-station was situated. 
Apart from these [post-stations], since couriers perforce travelled into various $k a z \bar{a}$ s not [containing post-stations] enregistered in the post-station registers and not situated on the main routes, the people of such każas maintained post-horses for couriers by mutual co-operation, themselves bearing the necessary expenses for the post-station.

This being so, on the matter of post-stations, not only does the Treasury suffer loss but also all [kinds of] oppression and tyranny are [visited on] the wretched peasantry. Therefore My firman has been issued, that on Rūz-i Hiżır [1] 108 [= 23 April 1697], each and every post-station in Rumeli and Anatolia is to be closed, and instead post-horses are to be supplied, like pack-horses (mekkāri misilliü), against a fee.

My firman has been given to this effect: Both at post-stations which are named and designated in the Register [of Post-Stations], and in każās where they are not named and not designated in the [said] Register, at the present time:

- How many post-horses are maintained in each?

- What are the annual expenses?

- How much cash do the post-station villages provide, and in return for what exemptions?

- In state post-stations, apart from the moneys supplied from the Treasury or by transfer of [local] revenues or that ordered to be paid as grants-in-aid in $<$ from? $>$ the [adjacent?] każās, how much money do [the local people] provide through the exigency of excess expenditure?

- In każās where there is no designated post-station, how much money do the people of the każā provide annually for the post-horses which they maintain?

- What is the distance in hours between each post-station and the next?

You are to investigate [these matters] accurately and also [to furnish], with legal attestation, the hourly distances of the post-stations [in your kazia $]$, and report in detail to My Imperial Stirrup for my Imperial Cognizance.

I have commanded that, on the arrival of $<$ N.N. $>$ with My Noble Order, you are to act conformably to My Order issued in this context, [and] moreover you are to enquire into the true and exact state of affairs concerning the aforementioned matter, and for My Imperial Cognizance you are to report in detail to My Imperial Stirrup.

Thus you are to know; you are to place reliance upon the Noble Sign.

Written on the fifteenth day of the month of Rebi 'ül-Ahir of the year one thousand, one hundred and eight.

In the Residence of Edirne the Well-Guarded

\section{[Annotated:]}

'It was received on 27 Cumā $7 \bar{a} ' l-A$ hir of the year $1108 . '$ 


\section{References}

BA KPT 2742: Defter-i menāzil-i Rūm İli ... 1104 (1692-1693) ilā ... 1105 (1693-1694).

BA KPT 3006: Defter-i menāzil-i ... ulak.der ... Rüm İli (1124-1125/1712-1713).

Fekete, L. (1955): Die Siyāqat-Schrift in der Türkischen Finanzverwaltung. I-II, Budapest.

Heywood, C. J. (1976-1977): Some Turkish Archival Sources for the History of the Menzilhane Network in Rumeli during the Eighteenth Century (Notes and Documents on the Ottoman Ulak, I). Boğaziçi Üniversitesi Dergisi - Beşeri Bilimler / Humanities iv-v, pp. 39-55.

Heywood, C. J. (1980): The Ottoman Menzilhane and Ulak System in Rumeli in the Eighteenth Century. Türkiye'nin Sosyal ve Ekonomik Tarihi (1071-1920). In: Inalcık, H.-Osman Okyar (eds) (1980): Birinci Uluslararası Türkiyen'nin Sosyal ve Ekonomik Tarihi Kongresi (Ankara, July 11-13, 1077) - Tebliğleri. Ankara, pp. 179-186.

Heywood, C. J. (1996): The Via Egnatia in the Ottoman Period: the Menzilhānes of the Sol Kol in the Late 17th/Early 18th Century. In: Zachariadou, E. (ed.) (1996): The Via Egnatia under Ottoman Rule (1380-1699). Rethymnon, pp. 129-144.

Sahillioğlu, H. (1970): Sıvış Year Crises in the Ottoman Empire. In: Cook, M. A. (ed.) (1970): Studies in the Economic History of the Middle East. Oxford, pp. 230-252. 